\title{
PROPOLIS: CHEMICAL COMPOSITION, BIOLOGICAL AND PHARMACOLOGICAL ACTIVITY - A REVIEW
}

\author{
Sanja Stojanović1, Stevo J. Najman¹, Biljana Bogdanova-Popov², Svetozar S. Najman³
}

\begin{abstract}
Propolis is a honey bee product that is well known from ancient times for its beneficial effects on human health and has been widely used in traditional medicine. Chemical composition of propolis is very complex and rich which is why propolis has many biological activities, but is dependent on the geographical origin and plant sources from which bees collect the material to produce propolis. Despite great diversity of its chemical composition, propolis has many biological and pharmacological activities and is widely used in medicine, dentistry and pharmacy. In this review, beneficial effects of propolis through its biological and pharmacological activities are discussed.
\end{abstract}

Acta Medica Medianae 2020;59(2):108-113. activity

Key words: propolis, chemical composition, biological activity, pharmacological

${ }^{1}$ University of Niš, Faculty of Medicine, Department of Biology and Human Genetics, Niš, Serbia

${ }^{2}$ University St. Kliment Ohridski - Bitola, E.S. Gjorgji Sugarev Bitola, Bitola, R. N. Macedonia

${ }^{3}$ University of Niš, Faculty of Medicine, Niš, Serbia

Contact: Sanja Stojanović

81. Dr Zoran Djindjić Blvd., 18000 Niš, Serbia

E-mail: sanja.stojanovic@medfak.ni.ac.rs

\section{Introduction}

Propolis, also called bee glue, is a natural resinous compound that is produced by honey bees. Honey bees collect the resins and other substances from various plant species, bring them back to the colony where they process it and utilize as propolis in the hives for a number of purposes. Not all species of the genus Apis (honey bee) produce and use propolis at the same degree (1-3). Among them, species Apis mellifera produces and utilizes propolis more than others (1-3). Both feral as well domesticated colonies use propolis, in tree cavities or commercial hives, for the same purposes such as covering the holes and sealing the cracks in the nest, narrowing the hive entrance creating a smooth surface for comb attachment, as an "embalming" substance and for the protection $(1,2,4)$. In addition to its role as a building material, propolis acts as physical, chemical and biological protector for the bees since it prevents uncontrolled airflow, acts as waterproofing wall against moisture, maintains constant humidity inside the hive, stabilizes the indoor temperature in the hive, creates protection against invaders, parasites and predators, acts as an antiseptic, prevents and inhibits the growth of pathogen microorganisms in the tree cavities and hives $(1,2,4,5)$. The word "propolis" originated from Ancient Greek word "pro" (which means "before" or in this context "in front of" or "at the entrance to") and the word "polis" (which means "the city" or "community" or in this context this may refer to the hive) $(1,2,4,6)$. This meaning of the word "propolis" is tightly connected to and refers to the main role of propolis as a substance that bees use to build the nest or the hive and its entrance which will serve for the protection and defense.

Learning from the bees and how they use propolis and for what purposes, people have been using propolis since ancient times. There are records suggesting the use of propolis by ancient Egyptians, Persians, Romans and Greeks for various purposes $(2,6,7)$. Although the propolis was mainly used as a remedy for medical purposes since ancient times (5), it was also used for other purposes as well. There are records that it was used as a constituent of violin varnish by famous Stradivari, Amati and others (8). Similar to the use of propolis as "embalming" substance by bees, Egyptians used propolis as an anti-putrefactive agent to embalm 
their dead (9). The Greeks used propolis as the primary ingredient of polyanthus, perfume which combined propolis, olibanum, styrax, and aromatic herbs $(2,8)$. As for medical purposes, it has been recorded that propolis was used as an antiseptic, cicatrizant and healing agent first by Greek and Roman physicians (9). The first data on the use of propolis for wound healing date back to the time of the Hippocrates who used propolis to cure wounds and ulcers, both external and internal (2). It is also known that Incas used propolis as an antipyretic agent while British pharmacopoeias (from the $17^{\text {th }}$ century) listed propolis as an official drug (9). The later use of propolis was mainly focused on its antibacterial properties (9).

So far, more than 300 chemical compounds of propolis have been identified and this number is still growing. The chemical composition of propolis varies greatly depending on the geographical and botanical origin, i.e. climate factors, plant resources and collecting seasons $(5,10)$. The specificity of the local flora is the major determinant of the chemical composition of propolis and subsequent biological and pharmacological activity. Due to its complexity and variable composition, there is a need for standardization of propolis in order to use it as a commercial product for medical purposes (5). Raw propolis is rarely used directly for the treatment although grinded propolis in the form of powder is used as an addition to the honey and other food formulations (8). Prior to the formulation of different preparations and their analysis, extraction of biologically active substances from propolis is generally carried out using water or different organic solvents. Extraction method as well as used solvents may significantly influence biological and pharmacological activities of propolis. Despite the variations in chemical composition, all propolis preparations exert wide variety of unique biological activities that are the characteristics of all propolis types, regardless of its origin, extraction method and composition. Propolis exhibits many biological and pharmacological activities and is widely used in various fields of medicine, dentistry and pharmacy. Propolis application potentials are increasing significantly.

\section{Chemical composition}

Propolis is mainly composed of the following components: resins and vegetable balsam (50\%), wax $(30 \%)$, essential oils $(10 \%)$, pollen $(5 \%)$, and other organic compounds including sugars, amino acids, vitamins, and minerals (5\%) (10-14). Except resins and waxes, the main groups of chemical compounds found to be present in propolis are: phenols (e.g., flavonoids, polyphenols, phenolic acids and other phenolic compounds) and their esters, terpenes and terpenoids, steroids, aromatic acids, aromatic esters, aldehydes, alcohols, sugars, sugar alcohols and acids, amino acids, vitamins, fatty acids, hydrocarbons, mineral elements and alcohols (12, 14-16). Major group of phenolic compounds presented in propolis is flavonoid group which contribute greatly to the biological and pharmacological activities of propolis. According to the chemical structure, flavonoids presented in propolis are classi- fied into: flavones, flavonols, flavanones, flavanonols, chalcones, dihydrochalcones, isoflavones, isodihydroflavones, flavans, isoflavans and neoflavonoids (12). Flavonoid group in propolis includes mainly the following substances: chrysin, pinocembrin, apigenin, rutin, luteolin, galangin, kaempferol, myricetin, catechin, naringenin, quercetin, tectochrysin, pinostrobin, acacetin and others (4, 13, 14, 17-19). Another important group of compounds found in propolis are phenolic acids, among which the most often are ferulic, cinnamic, caffeic, benzoic, salicylic and p-cumaric acids. In propolis other phenolic compounds (e.g., artepillin C) have been found as well as stilbenes and stilbene derivative resveratrol (12, $14,17)$. Volatile compounds such as terpenes and terpenoids are reported to be present in propolis in only $10 \%$ but greatly contribute to the biological and pharmacological activities of propolis and are responsible for its characteristic fragrance (12). Among them, terpineol, camphor, geraniol, nerol and farnesol have been identified so far $(4,13,18,19)$. It has been noticed that the presence of different types of terpenoids in propolis varies depending on the geographical origin of propolis $(4,13,18,19)$. Hydrocarbons such as alkanes, alkenes, alkadienes, monoesters, diesters, aromatic esters, fatty acids and steroids have been identified so far in many different types of propolis (12). Some enzymes like succinic dehydrogenase, glucose-6-phosphatase, adenosine triphosphatase and acid phosphatase are also found in propolis $(14,20)$. Minerals (macro- and microelements) which have been found in various propolis samples are $\mathrm{Ca}, \mathrm{K}, \mathrm{Na}, \mathrm{Mg}, \mathrm{Mn}, \mathrm{Fe}, \mathrm{Si}, \mathrm{Zn}$, $\mathrm{Se}, \mathrm{Cu}, \mathrm{Ni}, \mathrm{Al}, \mathrm{B}, \mathrm{Ba}, \mathrm{Cr}$ and $\mathrm{Sr}(4,13,14,18-20)$. The trace element profiles of propolis can be used for identification of different propolis samples based on their location. Some toxic elements such as As, $\mathrm{Cd}, \mathrm{Hg}$ and $\mathrm{Pb}$ have also been found in propolis (12, 21) especially in propolis samples collected from industrial and polluted areas which is why elements' analyses of raw propolis can be used as an indicator of environmental pollution. Propolis contains some important vitamins such as B complex vitamins, vitamins $C$ and $E(4,13,14,18-20)$. Most of the data on chemical composition of propolis have been obtained by analysis of different propolis extracts. For propolis dissolution and extraction of biologically active compounds, several different solvents can be used: water, alcohols (e.g. ethanol and methanol), glycols (e.g. propylene glycol), oils (e.g. olive oil) and in considerably less extent, and only for analytical purposes, other organic solvents such as hexane, acetone, dichloromethane and chloroform (19). It is also very common to use a mixture of aforementioned solvents especially water-ethanol mixtures (8). The most suitable extraction systems are hydroalcoholic solutions since propolis represents a mixture of polar and nonpolar compounds (22). Also, due to the lipophilic characteristic of some compounds and low solubility in water, commercial propolis formulations are often ethanol - or glycol-based (22). Despite the great variety of chemical compounds found in different propolis samples, there are some general groups of chemicals responsible for so called "basic" biological activities of propolis regardless of the specific compounds. 


\section{Biological and pharmacological activity}

Propolis and its extracts have numerous applications for the treatment of various diseases due to its great spectrum of biological activities. It has been found that propolis and its constituents possess antimicrobial (antibacterial, antiviral, antifungal), antioxidant, anti-inflammatory, immunomodulatory and anti-proliferative activities (6, 13, 14). Also, propolis and its components may stimulate the synthesis of extracellular matrix components (such as collagen), proliferation and migration of fibroblasts, differentiation of cells (6) and to possess both anti-apoptotic activity against normal cells while in the same time acts pro-apoptotic to some cancer cell lines. The activity of propolis depends on the chemical composition which is related to its geographical origin (19). Some biological activities of propolis are unique regardless of the propolis type and its origin (e.g. antimicrobial and antioxidant), while some specific biological functions depend on the presence of some biologically active compounds which is related to the botanical origin of propolis as well as to the extraction method that is used. Propolis, as a significant antimicrobial bee product, acts both against Gram-positive and Gramnegative bacteria, as well as aerobic and anaerobic bacteria with slightly higher activity against Grampositive bacteria $(6,23)$. Propolis exerts its antibacterial effect on two levels: by direct action on the microorganisms and by stimulation of the immune system which results in activation of the natural defense mechanisms of the organism (23).

Due to its rich chemical profile and wide variety of biological activities, propolis may have great pharmacological and therapeutical applications and can be used as natural antiseptic, anti-inflammatory, antioxidant, antimicrobial (antibacterial, antiviral, antifungal), anticancer, immunomodulatory and wound healing agent in various preparations and as a part or in addition to some medications for the treatment of wide variety of conditions and disorders $(6,13,14)$. So far, the following pharmacological properties of propolis have been reported: antiulcer, antacid, antihistaminergic, anti-inflammatory, antitumor, anesthetic properties, hepatoprotective, nephroprotective, cardioprotective, neuroprotective and pancreatoprotective activities (13, 14, 24-27). Furthermore, recent studies have revealed that propolis has hypoglycemic activity which may have positive impact on diabetic complications. It also modulates the metabolism of blood lipid levels which leads to a decrease in lipid peroxidation and scavenges the free radicals (27). The use of propolis has been proposed in some patents where propolis is suggested for the treatment of dental diseases, as an adjuvant in anti-cancer treatment, the use in cosmetic products, as an anti-inflammatory agent and as natural antibiotic (28). Hepatoprotective effect of propolis has been reported in many models of experimentally-induced hepatic injury in rats (16). Cardioprotective effect of Malaysian propolis against experimentally-induced ischemia in rats has been attributed to its anti-lipoperoxidative and antioxidant effects (26). Authors of this study suggested that this effect was probably achieved via two pathways, through direct radical-scavenging activities of propolis against ISO-induced oxidative stress and that propolis contributed to endogenous antioxidant enzyme activity via inhibition of lipid peroxidation (26). The protective effect of propolis against UVA-induced apoptosis of human keratinocyte HaCaT cells was observed and it was suggested that this effect might be related to the reduction of ROS generation by UVA-irradiation (29). Protective effects of propolis extract against ethylene glycol induced hepatotoxicity and nephrotoxicity has been reported, and it has been shown that treatment with propolis extract normalized the level of magnesium, sodium, potassium, chloride and creatinine, alleviated urinary protein excretion and ameliorated the deterioration of liver and kidney function caused by ethylene glycol, which candidates propolis for potential treatment and prevention of urinary calculus, crystalluria and proteinuria (30). Nephroprotective effect of propolis has also been shown against significant cisplatin caused damage of kidney tissue in dose-dependent manner (31). Propolis was proposed as an effective candidate for prevention or treatment of oxidative stress and neuroinflammation in neurological diseases since it has been reported that propolis and its flavonoid constituents exert neuroprotective properties in studies in vitro and in vivo through their antioxidant, anti-inflammatory, and immunomodulatory activities (25). Protective effects of propolis on the liver of diabetic rats have been reported and attributed to the suppression of oxidative stress, inflammation and apoptosis of hepatocytes, while in the same time increasing the proliferation of hepatocytes which altogether improves liver function in diabetic state (32). Synergistic protective effect of Malaysian propolis with metformin as a drug used in antihyperglycemic medication was observed in streptozotocin-induced diabetic rats (32) suggesting propolis as a promising complementary therapy in type 2 diabetes mellitus (T2DM). When the effects of Iranian propolis extract on glucose metabolism, lipid profile, insulin resistance, renal and liver function as well as inflammatory biomarkers were examined in patients with T2DM, it was shown that propolis has beneficial effects on reducing post prandial blood glucose, serum insulin, insulin resistance and inflammatory cytokines, while elevating HDL-C concentrations and prevent liver and renal dysfunction in patients with T2DM (27). Protective effects of ethanolic propolis extract on cardiovascular system and hepatorenal functions has been reported and attributed to the antihyperlipidemic and antioxidant activity of propolis which favors the traditional use of propolis in hyperlipidemic disorders as an adjuvant agent in the form of food supplement (33). Anticancer activity of propolis, alone or as an adjuvant therapy, has been shown against brain, head and neck, skin, breast, liver, pancreas, kidney, bladder, prostate, colon and blood cancers in various in vitro and in vivo studies (34). Due to the good bioavailability by the oral route and immunomodulatory activity, propolis is reported to be a good candidate for an adjuvant anticancer therapy (35). Caffeic acid phenethyl ester (CAPE) is a very potent biologically active substance isolated from propolis which, among others, has 
potent anticancer activity. It was shown that CAPE inhibited the proliferation and metastasis of nasopharyngeal carcinoma cells (NPC), enhanced the radiosensitivity of NPC cells and was synergistic in its action with chemotherapy and radiotherapy (36). Inhibition of the growth of breast cancer stem cells by CAPE has also been reported (37). Based on immunomodulatory effects of propolis which are shown to be achieved through the NO pathway and the effects on pro-inflammatory cytokines, some authors suggested that propolis may be a potential therapeutic candidate for modulation of inflammation in celiac disease (38). The use of propolis for the treatment of gynecological disorders has been reported due to its antimicrobial activities, especially against Candida species, as well as its anti-inflammatory activity (14). Propolis is proposed as an alternative treatment for chronic vaginitis, for an improvement in vaginal well-being, for recurrent vulvovaginal candidiasis and other gynecological disorders (14).

\section{Conclusion}

Propolis shows a great variety regarding composition which depends on its origin and plant sources from which is collected and produced. Different chemical composition may determine the specific biological activity of propolis, however, despite the variety in chemical composition, the biological and pharmacological activities of propolis are inevitable in many different examined model systems. The field of application of propolis is large and still growing, but given the variations in its composition that may influence its activity, it is necessary to carry out both detailed testing of each propolis preparation related to the origin as well as standardization of the preparation to the biologically active compounds that are mainly presented in propolis.

\section{References}

1. Simone-Finstrom M, Spivak M. Propolis and bee health: the natural history and significance of resin use by honey bees. Apidologie 2010;41:295-311. [CrossRef]

2. Kuropatnicki AK, Szliszka E, Krol W. Historical aspects of propolis research in modern times. Evid Based Complement Alternat Med 2013;2013:964149. [CrossRef] [PubMed]

3. Pujirahayu N, Suzuki T, Katayama T. CycloartaneType Triterpenes and Botanical Origin of Propolis of Stingless Indonesian Bee Tetragonula sapiens. Plants (Basel) 2019;8(3):E57. [CrossRef] [PubMed]

4. Bankova VS, De Castro SL, Marcucci MC. Propolis: recent advances in chemistry and plant origin. Apidologie 2000;31:3-15. [CrossRef]

5. Bankova V. Chemical diversity of propolis and the problem of standardization. J Ethnopharmacol 2005; 100(1-2):114-7. [CrossRef] [PubMed]

6. Martinotti S, Ranzato E. Propolis: a new frontier for wound healing? Burns Trauma 2015;3:9.
[CrossRef] [PubMed]

7. Suryati Mohd K, Elani Mat Nafi N, Shafiqha Abdul Khadar A, Awanis Mohd Badiazaman A, Rani Annisava A. Propolis: Traditional uses, Phytochemical Composition and Pharmacological Properties. International Journal of Engineering \& Technology 2018;7(4.43), 78-82.

8. Bogdanov S. Propolis: Composition, Health, Medicine: A Review. 2012; Available from: http://www.beehexagon.net/files/file/fileE/Health/PropolisBookReview .pdf.

9. Castaldo S, Capasso F. Propolis, an old remedy used in modern medicine. Fitoterapia 2002; 73 (Suppl 1): S1-6. [CrossRef] [PubMed]

10. Ristivojević P, Trifković J, Andrić F, MilojkovićOpsenica D. Poplar-type Propolis: Chemical Composition, Botanical Origin and Biological Activity. Nat Prod Commun 2015;10(11):1869-76. [CrossRef] [PubMed]

11. Gómez-Caravaca A, Gómez-Romero M, Arráez-Román D, Segura-Carretero A, Fernández-Gutiérrez A. 
Advances in the analysis of phenolic compounds in products derived from bees. J Pharmaceut Biomed 2006;41(4):1220-34. [CrossRef] [PubMed]

12. Huang S, Zhang C-P, Wang K, Li GQ, Hu F-L. Recent advances in the chemical composition of propolis. Molecules 2014;19(12):19610-32.

[CrossRef] [PubMed]

13. Sforcin JM. Biological Properties and Therapeutic Applications of Propolis. Phytother Res 2016; 30(6): 894-905. [CrossRef] [PubMed]

14. Pasupuleti VR, Sammugam L, Ramesh N, Gan SH. Honey, Propolis, and Royal Jelly: A Comprehensive Review of Their Biological Actions and Health Benefits. Oxid Med Cell Longev 2017;2017:1259510. [CrossRef] [PubMed]

15. Bankova V, Popova M, Trusheva B. Propolis volatile compounds: chemical diversity and biological activity: a review. Chem Cent J 2014;8:28. [CrossRef] [PubMed]

16. Madrigal-Santillán E, Madrigal-Bujaidar E, ÁlvarezGonzález I, Sumaya-Martínez MT, Gutiérrez-Salinas J, Bautista M, et al. Review of natural products with hepatoprotective effects. World J Gastroenterol 2014; 20(40):14787-804. [CrossRef] [PubMed]

17. Volpi N. Separation of flavonoids and phenolic acids from propolis by capillary zone electrophoresis. Electrophoresis 2004;25(12):1872-8. [CrossRef] [PubMed]

18. Zabaiou N, Fouache A, Trousson A, Baron S, Zellagui $A$, Lahouel $M$, et al. Biological properties of propolis extracts: Something new from an ancient product. Chem Phys Lipids 2017;207(Pt B):214-22. [CrossRef] [PubMed]

19. Przybyłek I, Karpiński TM. Antibacterial Properties of Propolis. Molecules 2019;24(11):E2047. [CrossRef] [PubMed]

20. Lotfy M. Biological activity of bee propolis in health and disease. Asian Pac J Cancer P 2006;7(1):22-31. [PubMed]

21. Cvek J, Medid-Saric M, Vitali D, Vedrina-Dragojevik I, Smit Z, Tomic S. The content of essential and toxic elements in Croatian propolis samples and their tinctures. J Apicult Res 2008;47:35-45. [CrossRef]

22. Alberti $T$, Coelho $D$, Voytena $A$, Iacovski $R$, Mazzarino L, Maraschin M, et al. Effect of Propolis Nanoparticles on Early-Stage Wound Healing in a Diabetic Noncontractile Wound Model. Nanotechnol Adv Mater Sci 2019;2(1):1-10.

23. Sforcin JM, Bankova V. Propolis: Is there a potential for the development of new drugs? J Ethnopharmacol 2011;133:253-60. [CrossRef] [PubMed]

24. Banskota AH, Tezuka Y, Kadota S. Recent progress in pharmacological research of propolis. Phytother Res 2001;15(7):561-71. [CrossRef] [PubMed]

25. Farooqui T, Farooqui AA. Beneficial effects of propolis on human health and neurological diseases. Front Biosci (Elite Ed) 2012;4:779-93. [CrossRef] [PubMed]

26. Ahmed R, Tanvir EM, Hossen MS, Afroz R, Ahmmed I, Rumpa NE, et al. Antioxidant Properties and Cardioprotective Mechanism of Malaysian Propolis in Rats.
Evid Based Complement Alternat Med 2017; 2017: 5370545. [CrossRef] [PubMed]

27. Zakerkish M, Jenabi M, Zaeemzadeh N, Hemmati AA, Neisi N. The Effect of Iranian Propolis on Glucose Metabolism, Lipid Profile, Insulin Resistance, Renal Function and Inflammatory Biomarkers in Patients with Type 2 Diabetes Mellitus: A Randomized DoubleBlind Clinical Trial. Sci Rep 2019;9(1):7289.

[CrossRef] [PubMed]

28. de Figueiredo SM, Nogueira-Machado JA, Almeida Bde M, Abreu SR, de Abreu JA, Filho SA, et al. Immunomodulatory properties of green propolis. Recent Pat Endocr Metab Immune Drug Discov 2014;8(2):85-94. [CrossRef] [PubMed]

29. Kim HB, Yoo BS. Propolis Inhibits UVA-Induced Apoptosis of Human Keratinocyte HaCaT Cells by Scavenging ROS. Toxicol Res 2016; 32(4):345-351. [CrossRef] [PubMed]

30. El Menyiy N, Al Waili N, Bakour M, Al-Waili H, Lyoussi B. Protective Effect of Propolis in Proteinuria, Crystaluria, Nephrotoxicity and Hepatotoxicity Induced by Ethylene Glycol Ingestion. Arch Med Res 2016; 47(7):526-34. [CrossRef] [PubMed]

31. Yuluğ E, Türedi S, Yıldırım Ö, Yenilmez E, Aliyazıcıoğlu Y, Demir S, et al. Biochemical and morphological evaluation of the effects of propolis on cisplatin induced kidney damage in rats. Biotech Histochem 2019;94(3):204-13. [CrossRef] [PubMed]

32. Nna VU, Bakar ABA, Mohamed M. Malaysian propolis, metformin and their combination, exert hepatoprotective effect in streptozotocin-induced diabetic rats. Life Sci 2018;211:40-50. [CrossRef] [PubMed]

33. Oršolić N, Landeka Jurčević I, Đikić D, Rogić D, Odeh D, Balta V, et al. Effect of Propolis on Diet-Induced Hyperlipidemia and Atherogenic Indices in Mice. Antioxidants (Basel) 2019;8(6): E156. [CrossRef] [PubMed]

34. Patel S. Emerging Adjuvant Therapy for Cancer: Propolis and its Constituents. J Diet Suppl 2016; 13(3):245-68. [CrossRef] [PubMed]

35. Chan GC, Cheung KW, Sze DM. The immunomodulatory and anticancer properties of propolis. Clin Rev Allergy Immunol 2013;44(3):262-73. [CrossRef] [PubMed]

36. Liang Y, Feng G, Wu L, Zhong S, Gao X, Tong Y, et al. Caffeic acid phenethyl ester suppressed growth and metastasis of nasopharyngeal carcinoma cells by inactivating the NF-KB pathway. Drug Des Devel Ther 2019;13:1335-45. [CrossRef] [PubMed]

37. Omene $\mathrm{CO}, \mathrm{Wu}$ J, Frenkel K. Caffeic acid phenethyl ester (CAPE) derived from propolis, a honeybee product, inhibits growth of breast cancer stem cells. Investig New Drugs 2012;30:1279-88. [CrossRef] [PubMed]

38. Medjeber O, Touri K, Rafa H, Djeraba Z, Belkhelfa M, Boutaleb $A F$, et al. Ex vivo immunomodulatory effect of ethanolic extract of propolis during Celiac Disease: involvement of nitric oxide pathway. Inflammopharmacology 2018;26(6):1469-81.

[CrossRef] [PubMed] 


\title{
PROPOLIS: HEMIJSKI SASTAV, BIOLOŠKA I FARMAKOLOŠKA AKTIVNOST - PREGLED
}

\author{
Sanja Stojanović ${ }^{1}$, Stevo J. Najman ${ }^{1}$, Biljana Bogdanova-Popov², Svetozar S. Najman³ \\ ${ }^{1}$ Univerzitet u Nišu, Medicinski fakultet, Institut za biologiju i humanu genetiku, Niš, Srbija \\ ¿University St. Kliment Ohridski - Bitola, E.S. Gjorgji Sugarev - Bitola, Bitola, R. Severna Makedonija \\ ${ }^{3}$ Univerzitet u Nišu, Medicinski fakultet, Niš, Srbija \\ Kontakt: Sanja Stojanović \\ Bulevar dr Zorana Đinđića 81, 18000 Niš, Srbija \\ E-mail: sanja.stojanovic@medfak.ni.ac.rs
}

Propolis je pčelinji proizvod koji je od davnina poznat po svojim povoljnim efektima na zdravlje ljudi i koji je u širokoj upotrebi u tradicionalnoj medicini. Hemijski sastav propolisa je veoma složen zbog čega propolis poseduje mnoge biološke aktivnosti, ali zavisi od geografskog porekla i biljnih izvora iz kojih pčele sakupljaju materijal za proizvodnju propolisa. Uprkos velikoj raznovrsnosti svog hemijskog sastava, propolis poseduje mnoge biološke i farmakološke aktivnosti i u širokoj je upotrebi u medicini, stomatologiji i farmaciji. U ovom pregledu razmatrani su povoljni efekti propolisa kroz njegove biološke i farmakološke aktivnosti.

Acta Medica Medianae 2020;59(2):108-113.

Ključne reči: propolis, hemijski sastav, biološka aktivnost, farmakološka aktivnost 